\title{
Climatization-Negligent Attribution of Great Salt Lake Desiccation: A Comment on Meng (2019)
}

\author{
Michael L. Wine ${ }^{1, * \mathbb{D}}$, Sarah E. Null ${ }^{2}$, R. Justin DeRose ${ }^{3}$ and Wayne A. Wurtsbaugh ${ }^{2}$ \\ 1 Geomorphology and Fluvial Research Group, Ben Gurion University of the Negev, Beer Sheva 8410501, Israel \\ 2 Department of Watershed Sciences \& Ecology Center, Utah State University, Logan, UT 84322, USA; \\ sarah.null@usu.edu (S.E.N.); wayne.wurtsbaugh@usu.edu (W.A.W.) \\ 3 Rocky Mountain Research Station, US Forest Service, Ogden, UT 84401, USA; rjderose@fs.fed.us \\ * Correspondence: mlw63@me.com
}

Received: 29 March 2019; Accepted: 11 May 2019; Published: 14 May 2019

\begin{abstract}
A recent article reviewed data on Great Salt Lake (Utah) and concluded falsely that climate changes, especially local warming and extreme precipitation events, are primarily responsible for lake elevation changes. Indeed climatically influenced variation of net inflows contribute to huge swings in the elevation of Great Salt Lake (GSL) and other endorheic lakes. Although droughts and wet cycles have caused lake elevation changes of over $4.5 \mathrm{~m}$, they have not caused a significant long-term change in the GSL stage. This recent article also suggests that a $1.4{ }^{\circ} \mathrm{C}$ rise in air temperature and concomitant increase in the lake's evaporative loss is an important reason for the lake's decline. However, we calculate that a $1.4{ }^{\circ} \mathrm{C}$ rise may have caused only a $0.1 \mathrm{~m}$ decrease in lake level. However, since 1847, the lake has declined $3.6 \mathrm{~m}$ and the lake area has decreased by $\approx 50 \%$, despite no significant change in precipitation $(p=0.52)$ and a slight increase, albeit insignificant, in river flows above irrigation diversions $(p=0.085)$. In contrast, persistent water extraction for agriculture and other uses beginning in 1847 now decrease water flows below diversions by $39 \%$. Estimates of consumptive water use primarily for irrigated agriculture in the GSL watershed suggest that approximately $85 \%$ $\left(2500 \mathrm{~km}^{2}\right)$ of the reduced lake area can be attributed to human water consumption. The recent article's failure to calculate a water budget for the lake that included extensive water withdrawals misled the author to focus instead on climate change as a causal factor for the decline. Stable stream flows in GSL's headwaters, inadequate temperature increase to explain the extent of its observed desiccation, stable long-term precipitation, and the magnitude of increased water consumption from GSL together demonstrate conclusively that climatic factors are secondary to human alterations to GSL and its watershed. Climatization, in which primarily non-climatic processes are falsely attributed to climatic factors, is a threat to the credibility of hydrological science. Despite a recent suggestion to the contrary, pressure to support Earth's rising human population-in the form of increasing consumption of water in water-limited regions, primarily to support irrigated agriculture-remains the leading driver of desiccation of inland waters within Earth's water-limited regions.
\end{abstract}

Keywords: Aral Sea Syndrome; Anthropocene; agriculture; water balance; saline lake; global change

\section{Introduction}

Meng [1] examines the water balance of the Great Salt Lake (GSL), Utah, USA, and determines that "climate changes, especially local warming and extreme weather including both precipitation and temperature, drive the dynamics (increases and declines) of the GSL surface levels," contradicting a large body of research implicating human water consumption as the primary driver of shrinkage among lakes in Earth's water-limited regions [2-18]. We therefore critically examine the methods and claims of [1]. 


\section{Errors of Prior Publication}

\subsection{Mistaken Water Balance}

Meng's [1] definition of inflows is erroneous in that it fails to account for how human water consumption reduces river discharge. Instead the river discharge term is mistakenly assumed to be free of human influence. Water withdrawals for agricultural and municipal uses in the GSL watershed can be substantial, and appropriately accounting for them is standard practice when developing stream flow reconstructions. Reconstructions of important GSL tributaries (i.e., Logan River, Weber River, and Bear River) have all focused on upper headwater gages for precisely this reason [19-21]. Meng [1] incorrectly states the water balance of GSL as:

"GSL water level $=$ inflow (precipitation + river discharge)—outflow (human water use + evaporation)"

This water balance equation is in error as the units are inhomogeneous, with water level in units of depth and flows in units of volume. The standard water balance equation balances changes in storage in the control volume $(\Delta S)$ with volumetric inflows (Q_IN) less outflows (Q_OUT), all in units of volume per time: $\Delta S=$ Q_IN - Q_OUT. Consumptive water uses reduce inflows to Great Salt Lake rather than increase outflows from the lake as [1] asserted.

\subsection{Impacts of Rising Temperatures}

Meng [1] claims that "from the early 1970s, there is a significant trend of local climate warming in the GSL region, which is primarily driving the declines of the GSL." While the temperature trend since the 1970s is legitimate, it is in part a local manifestation of global warming. Meng [1] provides no quantitative evidence that lake evaporation flux rates have in fact increased or if so, by how much. Nevertheless, a $1.4^{\circ} \mathrm{C}$ increase in air temperature has likely increased lake evaporation and contributed to the decline in lake level, but far less than implied by [1]. Following the approach of [22], a modified Penman equation was used to estimate open water evaporation as a consequence of warming air temperature while accounting for reduced evaporation rates due to increased lake salinity. The reported $1.4{ }^{\circ} \mathrm{C}$ rise in temperature would have lowered the lake $0.12 \mathrm{~m}$, whereas lake elevation actually fell $0.81 \mathrm{~m}$ (USGS data) over the last 46 years. Consequently, increases in lake evaporation due to temperature increases are important, but are insufficient to explain the decline in the Great Salt Lake. Any future changes in air temperature due to global climate change would have additional impacts, although these are likely to have a larger influence on evapotranspiration in the watershed than on the lake itself [23]. Other studies have empirically correlated temperature increases with the shrinkage of lakes [24-28]. However, those studies that have also quantified the role of rising temperature on agricultural evapotranspiration have found that warming-driven lake evaporation changes remain of lesser importance, relative to agricultural water consumption, given the level of observed warming at present [17].

Meng [1] makes a variety of additional claims concerning temperature increases that are unsupported by past research:

In contrast to the claim that "evaporation caused by the increases in temperature can be the dominant water loss of saline lakes," past work has shown that: (1) Predicted increases in lake evaporation are small in the near-term (0.1-0.25\% per year [29]); and (2) a range of factors control evaporation from open water, of which temperature is only one. Thus, ref. [30] found that evaporation was lower on warmer days when the wind was weaker as a result of synoptic weather conditions. Additionally, lake evaporation is the product of lake area and evaporative flux. With lakes in water-limited systems shrinking globally [18], evaporative fluxes decrease proportionally to lost lake area [31], and with increasing salinity [22,32].

The claim that "climate changes, especially increasing temperature, have caused significant water loss through evaporation in semi-arid regions" confuses substantial future increases in lake evaporation 
predicted to transpire by the end of the century [33] with substantially smaller increases in evaporation from lakes that may have actually already occurred [17,29].

The suggestion that "increasing evaporation rates caused by climate warming have resulted in approximately $40 \%$ of Australia's total water storage capacity loss every year" is also misleading as this loss is not a result of anthropogenic climate change, but rather primarily a consequence of natural conditions of high evaporative demand [34].

\subsection{Drivers of Changing Streamflow}

Meng [1] postulates that "reduced river discharge is directly caused by the declining precipitation and snowfall," even though ref. [18] found that there has been no significant decline in precipitation in the basin over a long timeframe (1875-2015; $p=0.52)$. They also found that there was a slight upward trend, albeit insignificant $(p=0.085)$, in headwater streamflow above irrigation diversions since pioneers began developing water resources in the mid-1800s. In contrast, river flows reaching the Great Salt Lake have decreased by 39\% due to water development for agriculture and other human uses, which has significantly $(p<0.0001)$ reduced lake elevation by $3.6 \mathrm{~m}$ (Figure 1) [18]. Meng's [1] analysis of the 1904-2016 precipitation, temperature, and lake level records is misleading because it ignores the data showing that approximately $80 \%$ of water development for agriculture and other uses occurred before 1904 (Figure 1) [18].

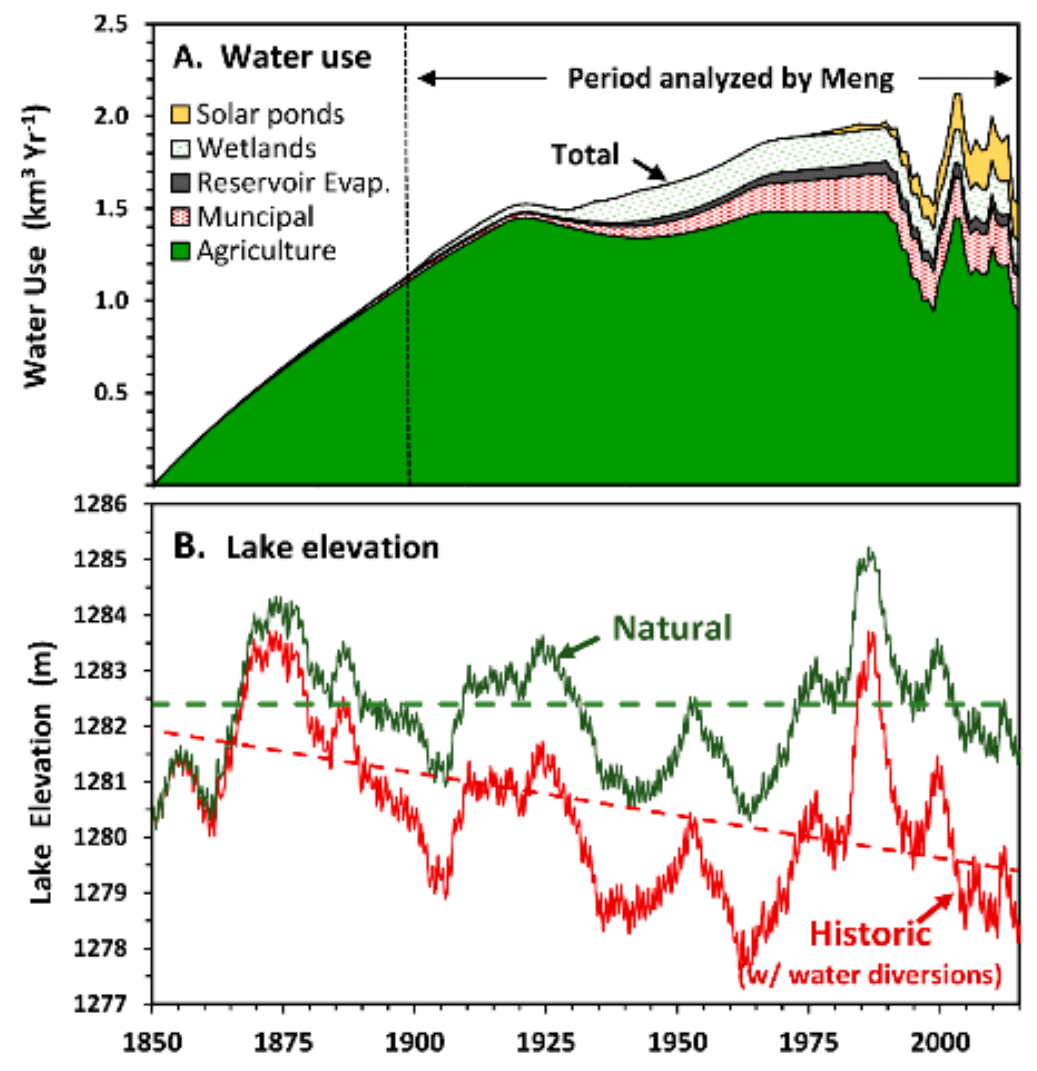

Figure 1. (A) Estimated water use for agriculture and other applications in the Great Salt Lake watershed from 1850-2013. Note that [1] failed to analyze the period from 1850-1903, during which approximately $80 \%$ of water development occurred. See [18] for methods. (B) Yearly and long-term changes in the actual elevation of the south basin of Great Salt Lake derived from the U.S. Geological Survey data (red). Droughts and wet years emphasized by [1] cause large swings in lake elevation but cannot account for the significant $(p<0.001)$ decline since water development began in the basin. The green line shows [18] estimate of the natural lake elevation if consumptive water use had not occurred. The lake has declined approximately $3.6 \mathrm{~m}$ due to consumptive water use. 
Additional analyses show that when all long-term and active stream gages in the Great Salt Lake watershed are considered, Meng's [1] assertion that decreasing precipitation is reducing streamflows is erroneous (Figure 2). In low order headwater streams above agricultural diversions, streamflow is stable. In contrast, in higher order rivers proximal to irrigated agricultural areas, streamflow decreases are observed. Indeed, such a pattern is a telltale sign of increasing agricultural water consumption over time [5]. As of 2015, GSL had shrunk by $2874 \mathrm{~km}^{2}$ from $5966 \mathrm{~km}^{2}$ [35]. In the Great Salt Lake watershed, $3894 \mathrm{~km}^{2}$ of agricultural land is irrigated [36]. MODerate resolution Imaging Spectroradiometer (MODIS)-derived annual evapotranspiration (ET) for irrigated areas in the GSL watershed suggest mean ET is $370 \mathrm{~mm} \cdot \mathrm{yr}^{-1}$ [37], implying an annual consumption of water for irrigated agriculture in the GSL basin of $1.5 \times 10^{9} \mathrm{~m}^{3} \cdot \mathrm{yr}^{-1}$, similar to the estimate by [18]. If evaporation excess (evaporation-direct precipitation) from the lake's surface is $0.61 \mathrm{~m} \cdot \mathrm{yr}^{-1}$ on average [22], then approximately $2500 \mathrm{~km}^{2}$ of the reduced lake area can be attributed to irrigated agriculture, over $85 \%$ of the observed lake area loss.

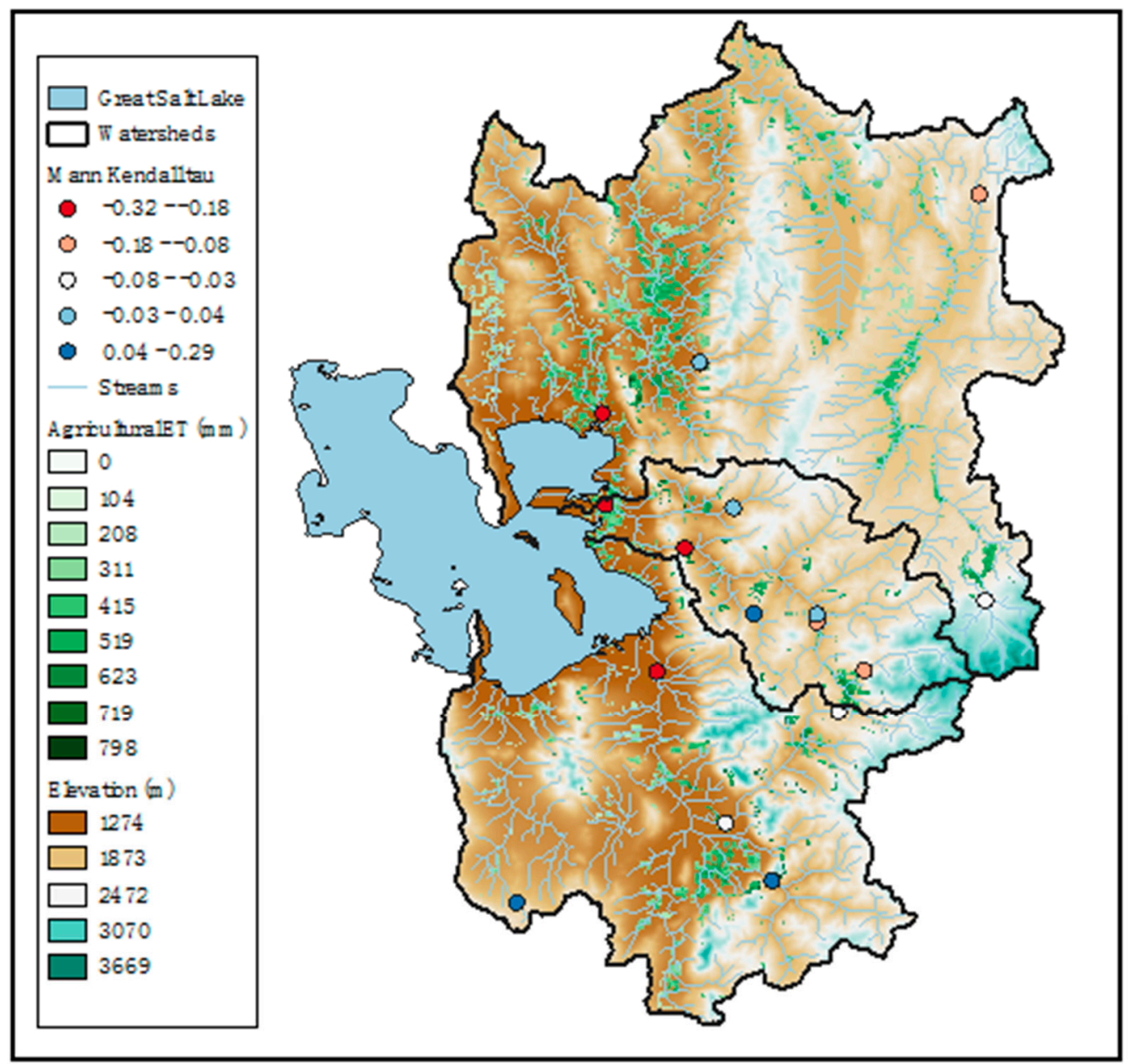

Figure 2. River discharge trends and irrigated agriculture in the Great Salt Lake watershed. Dots show long-term ( $\geq 50$ year) discharge trends through 2018 in 16 rivers. Streamflow is steady in low order headwater streams. Only higher order rivers that discharge into the lake have sharply decreasing streamflow. This is consistent with increasing water consumption from irrigated agriculture. (Mann Kendall tau values indicate the strength and direction of a trend over time).

\subsection{Time Scales}

Meng [1] highlights extreme weather events, which he suggests support an extremely changing point analysis of "the so-called current declines of the world's saline lakes". He describes "extreme weather events" as those that are more that \pm 2 S.D. of the mean. Meng [1] is correct that periods of 
extreme precipitation or drought cause large changes in runoff and the level of Great Salt Lake. This is true for all closed-basin lakes (e.g., Lake Abert-[9]; Lake Urmia-[3]). For example, above average precipitation in the Great Salt Lake watershed from 1967-1981 increased the lake level by $2.0 \mathrm{~m}$ and then back-to-back 100-year precipitation events of 1982 and 1983 increased the lake level by another $2.4 \mathrm{~m}$. This phenomenal increase, however, was followed by a $5.0 \mathrm{~m}$ decrease from 1987 to 2016, when the lake reached its lowest recorded level of $1277.5 \mathrm{~m}$ [18]. Meng incorrectly indicated that the lake's lowest level was in 1963 because he failed to calculate changes in both the north and south arms of the lake that are divided by a causeway [38]. Meng's analysis highlights the importance of weather-induced changes in the quasi-cyclic elevations of saline lakes, but without conducting a careful water balance analysis, he failed to identify the more important long-term driver of change in most saline lakes: persistent water withdrawals from their tributaries for agricultural and other forms of evaporative consumption $[2,5-10,12,18,39,40]$.

\section{Conclusions}

The dominance of water development, rather than climate change, for influencing most saline lakes has important implications for managers. A warming climate and changes in precipitation will have very important consequences for saline lakes and other ecosystems. Managers should not, however, let climate change and the high variability of these ecosystems obscure the very real desiccation of saline lakes caused by water development. Meng's erroneous analysis is an example of climatization, in which primarily non-climatic processes are falsely attributed to climatic factors $[13,15,16,41]$, thus absolving local governments of responsibility for sustainable management. In many cases, discriminating between climate impacts and water development $[2,12,18,42]$ will only be understood with more thorough analyses than those attempted by [1]. Managers must be aware of this issue and support thorough water balance analyses, and then take the appropriate actions to preserve these ecosystems [43]. We support the recommendation of [44] that: "Aquatic ecosystems may be most effectively managed in the context of global climate change if both the more pressing anthropogenic threats [of water development] and the occurrence of extreme events are considered and incorporated into management plans."

Author Contributions: All authors contributed to conceptualization, investigation, and writing.

Acknowledgments: The comments of two anonymous reviewers were appreciated.

Conflicts of Interest: The authors declare no conflicts of interest.

\section{References}

1. Meng, Q. Climate Change and Extreme Weather Drive the Declines of Saline Lakes: A Showcase of the Great Salt Lake. Climate 2019, 7, 19. [CrossRef]

2. AghaKouchak, A.; Norouzi, H.; Madani, K.; Mirchi, A.; Azarderakhsh, M.; Nazemi, A.; Nasrollahi, N.; Farahmand, A.; Mehran, A.; Hasanzadeh, E. Aral Sea syndrome desiccates Lake Urmia: Call for action. J. Gt. Lakes Res. 2015, 41, 307-311. [CrossRef]

3. Alborzi, A.; Mirchi, A.; Moftakhari, H.; Mallakpour, I.; Alian, S.; Nazemi, A.; Hassanzadeh, E.; Mazdiyasni, O.; Ashraf, S.; Madani, K.; et al. Climate-informed environmental inflows to revive a drying lake facing meteorological and anthropogenic droughts. Environ. Res. Lett. 2018, 13. [CrossRef]

4. Chaudhari, S.; Felfelani, F.; Shin, S.; Pokhrel, Y. Climate and anthropogenic contributions to the desiccation of the second largest saline lake in the twentieth century. J. Hydrol. 2018, 560, 342-353. [CrossRef]

5. Fazel, N.; Haghighi, A.T.; Klove, B. Analysis of land use and climate change impacts by comparing river flow records for headwaters and lowland reaches. Glob. Planet. Chang. 2017, 158, 47-56. [CrossRef]

6. Khazaei, B.; Khatami, S.; Alemohammad, S.H.; Rashidi, L.; Wu, C.; Madani, K.; Kalantari, Z.; Destouni, G.; Aghakouchak, A. Climatic or regionally induced by humans? Tracing hydro-climatic and land-use changes to better understand the Lake Urmia tragedy. J. Hydrol. 2019, 569, 203-217. [CrossRef] 
7. Micklin, P.P. Desiccation of the Aral Sea-A Water Management Disaster in the Soviet-Union. Science 1988, 241, 1170-1175. [CrossRef]

8. Micklin, P. The Aral Sea Disaster. Annu. Rev. Earth Planet. Sci. 2007, 35, 47-72. [CrossRef]

9. Moore, J.N. Recent desiccation of Western Great Basin Saline Lakes: Lessons from Lake Abert, Oregon, U.S.A. Sci. Total Environ. 2016, 554-555, 142-154. [CrossRef]

10. Morin, E.; Ryb, T.; Gavrieli, I.; Enzel, Y. Mean, variance, and trends of Levant precipitation over the past 4500 years from reconstructed Dead Sea levels and stochastic modeling. Quatern. Res. 2018. [CrossRef]

11. Rodell, M.; Famiglietti, J.S.; Wiese, D.N.; Reager, J.T.; Beaudoing, H.K.; Landerer, F.W.; Lo, M.H. Emerging trends in global freshwater availability. Nature 2018, 557, 651-659. [CrossRef]

12. Wang, J.; Song, C.; Reager, J.T.; Yao, F.; Famiglietti, J.S.; Sheng, Y.; MacDonald, G.M.; Brun, F.; Schmied, H.M.; Marston, R.A.; et al. Recent global decline in endorheic basin water storages. Nat. Geosci. 2018, 11, 926-932. [CrossRef] [PubMed]

13. Wine, M.L. Under non-stationarity securitization contributes to uncertainty and Tragedy of the Commons. J. Hydrol. 2019, 568, 716-721. [CrossRef]

14. Wine, M.L. Response to comment on "agriculture, diversions, and drought shrinking Galilee Sea". Sci. Total Environ. 2019, 663, 436-437. [CrossRef]

15. Wine, M.L. There is no black hole swallowing water in the Hula Valley. Land Use Policy 2019, 84, 363-364. [CrossRef]

16. Wine, M.L. Letter to editor re Tal (2019): Climaticization of environmental degradation-An Anthropocene epoch response to failure of governance. Sci. Total Environ. 2019. [CrossRef]

17. Wine, M.L.; Rimmer, A.; Laronne, J.B. Agriculture, diversions, and drought shrinking Galilee Sea. Sci. Total Environ. 2019, 651, 70-83. [CrossRef] [PubMed]

18. Wurtsbaugh, W.A.; Miller, C.; Null, S.E.; DeRose, R.J.; Wilcock, P.R.; Hahnenberger, M.; Howe, F.; Moore, J.N. Decline of the world's saline lakes. Nat. Geosci. 2017, 10, 816-821. [CrossRef]

19. Allen, E.B.; Rittenour, T.M.; DeRose, R.J.; Bekker, M.F.; Kjelgren, R.; Buckley, B.M. A tree-ring based reconstruction of Logan River streamflow, northern Utah. Water Resour. Res. 2013, 49, 8579-8588. [CrossRef]

20. Bekker, M.F.; Justin DeRose, R.; Buckley, B.M.; Kjelgren, R.K.; Gill, N.S. A 576-Year Weber River Streamflow Reconstruction from Tree Rings for Water Resource Risk Assessment in the Wasatch Front, Utah. JAWRA J. Am. Water Resour. Assoc. 2014, 50, 1338-1348. [CrossRef]

21. DeRose, R.J.; Bekker, M.F.; Wang, S.Y.; Buckley, B.M.; Kjelgren, R.K.; Bardsley, T.; Rittenour, T.M.; Allen, E.B. A millennium-length reconstruction of Bear River stream flow, Utah. J. Hydrol. 2015, 529, 524-534. [CrossRef]

22. Mohammed, I.N.; Tarboton, D.G. An examination of the sensitivity of the Great Salt Lake to changes in inputs. Water Resour. Res. 2012, 48. [CrossRef]

23. Huntington, T.G. Evidence for intensification of the global water cycle: Review and synthesis. J. Hydrol. 2006, 319, 83-95. [CrossRef]

24. Chen, J.L.; Pekker, T.; Wilson, C.R.; Tapley, B.D.; Kostianoy, A.G.; Cretaux, J.F.; Safarov, E.S. Long-term Caspian Sea level change. Geophys. Res. Lett. 2017, 44, 6993-7001. [CrossRef]

25. Fathian, F.; Morid, S.; Kahya, E. Identification of trends in hydrological and climatic variables in Urmia Lake basin, Iran. Theor. Appl. Climatol. 2014, 119, 443-464. [CrossRef]

26. Fathian, F.; Dehghan, Z.; Bazrkar, M.H.; Eslamian, S. Trends in hydrological and climatic variables affected by four variations of the Mann-Kendall approach in Urmia Lake basin, Iran. Hydrol. Sci. J. 2016. [CrossRef]

27. Liu, H.; Yin, Y.; Piao, S.; Zhao, F.; Engels, M.; Ciais, P. Disappearing lakes in semiarid Northern China: Drivers and environmental impact. Environ. Sci. Technol. 2013, 47, 12107-12114. [CrossRef] [PubMed]

28. Zheng, J.J.; Ke, C.Q.; Shao, Z.D.; Lie, F. Monitoring changes in the water volume of Hulun Lake by integrating satellite altimetry data and Landsat images between 1992 and 2010. J. Appl. Remote Sens. 2016, 10, 14. [CrossRef]

29. Rimmer, A.; Givati, A.; Samuels, R.; Alpert, P. Using ensemble of climate models to evaluate future water and solutes budgets in Lake Kinneret, Israel. J. Hydrol. 2011, 410, 248-259. [CrossRef]

30. Shilo, E.; Ziv, B.; Shamir, E.; Rimmer, A. Evaporation from Lake Kinneret, Israel, during hot summer days. J. Hydrol. 2015, 528, 264-275. [CrossRef]

31. Zhan, S.; Song, C.; Wang, J.; Sheng, Y.; Quan, J. A Global Assessment of Terrestrial Evapotranspiration Increase Due to Surface Water Area Change. Earth's Future 2019. [CrossRef] 
32. Zilberman, T.; Gavrieli, I.; Yechieli, Y.; Gertman, I.; Katz, A. Constraints on evaporation and dilution of terminal, hypersaline lakes under negative water balance: The Dead Sea, Israel. Geochim. Cosmochim. Acta 2017, 217, 384-398. [CrossRef]

33. Wang, W.; Lee, X.; Xiao, W.; Liu, S.; Schultz, N.; Wang, Y.; Zhang, M.; Zhao, L. Global lake evaporation accelerated by changes in surface energy allocation in a warmer climate. Nat. Geosci. 2018, 11, 410-414. [CrossRef]

34. Helfer, F.; Lemckert, C.; Zhang, H. Impacts of climate change on temperature and evaporation from a large reservoir in Australia. J. Hydrol. 2012, 475, 365-378. [CrossRef]

35. Lehner, B.; Döll, P. Development and validation of a global database of lakes, reservoirs and wetlands. J. Hydrol. 2004, 296, 1-22. [CrossRef]

36. Meier, J.; Zabel, F.; Mauser, W. A global approach to estimate irrigated areas-A comparison between different data and statistics. Hydrol. Earth Syst. Sci. 2018, 22, 1119-1133. [CrossRef]

37. Mu, Q.; Zhao, M.; Running, S.W. Improvements to a MODIS global terrestrial evapotranspiration algorithm. Remote Sens. Environ. 2011, 115, 1781-1800. [CrossRef]

38. White, J.S.; Null, S.E.; Tarboton, D.G. How Do Changes to the Railroad Causeway in Utah's Great Salt Lake Affect Water and Salt Flow? PLoS ONE 2015, 10, e0144111. [CrossRef] [PubMed]

39. Hostetler, S.W.; Giorgi, F. Effects of a $2 \times \mathrm{CO} 2$ climate on two large lake systems: Pyramid Lake, Nevada, and Yellowstone Lake, Wyoming. Glob. Planet. Chang. 1995, 10, 43-54. [CrossRef]

40. Williams, W.D. Conservation of salt lakes. Hydrobiologia 1993, 267, 291-306. [CrossRef]

41. Grant, S.; Tamason, C.C.; Jensen, P.K.M. Climatization: A critical perspective of framing disasters as climate change events. Clim. Risk Manag. 2015, 10, 27-34. [CrossRef]

42. Gao, H.; Bohn, T.J.; Podest, E.; McDonald, K.C.; Lettenmaier, D.P. On the causes of the shrinking of Lake Chad. Environ. Res. Lett. 2011, 6, 7. [CrossRef]

43. Edwards, E.C.; Null, S.E. The cost of addressing saline lake level decline and the potential for water conservation markets. Sci. Total Environ. 2019, 651, 435-442. [CrossRef] [PubMed]

44. Grimm, N.B.; Chacón, A.; Dahm, C.N.; Hostetler, S.W.; Lind, O.T.; Starkweather, P.L.; Wurtsbaugh, W.A. Sensitivity of aquatic ecosystems to climatic and anthropogenic changes: The Basin and Range, American Southwest and Mexico. Hydrol. Process. 1997, 11, 1023-1041. [CrossRef] 